Further information about the content of the course will be provided by the end of 1998 . The course is intended to provide a comprehensive review of genetics and should be particularly helpful for trainees planning to take the American Board of Medical Genetics and the American Board of Genetic Counseling examinations in 1999. We thank Arthur Beaudet of Baylor College of Medicine for his willingness to turn over this outstanding educational activity to the ACMG.

The Education/CME Committee chair has passed from Jessica Davis to Bruce Korf. New members on the committee are Mary Curtis and Cynthia Powell. Two new members will be added every year to succeed committee members who complete their four-year terms.

\section{Joint Committee on Professional Practice and Clinical Guidelines}

Michael M. Kaback, MD, Chair

The committee met on February 26, 1998, in Los Angeles at the Fifth Joint Clinical Genetics Conference. Completion of the cancer genetics guidelines draft and the lengthy review process were discussed. The committee carefully analyzed the latest draft of the congenital malformations guidelines; suggestions were considered and incorporated. Additional funds for dissemination and evaluation of this document have been secured through a grant from the CDC Centers of Excellence for Birth Defects Prevention. The committee would like to review the new compendium of guidelines produced by the American Academy of Pediatrics Genetics Committee. Other clinical issues needing guideline development were deliberated. Two possible topics are the assessment of the family with history of mental retardation and a work-up of the newborn with ambiguous genitalia.

The committee sponsored a workshop at the conference entitled "Clinical Practice Guidelines for Congenital Malformations." The workshop was moderated by Michael Kaback and included presentations by Keith Servis (New York State Department of Health), Karen Greendale, Cheryl Reid, and Frank Desposito. Karen Greendale presented "Cancer, Genetics and the Public's Health," a talk on the development of the cancer genetics guidelines at the Annual Council of Regional Networks for Genetic Services meeting in Decatur, GA.

\section{Clinical Practice Committee}

\section{Lewis B. Holmes, MD, Chair}

The Clinical Practice Committee of the ACMG focuses on issues of concern to practicing clinical geneticists. In discussions and position statements we have addressed Cystic Fibrosis (CF) screening, the addition of screening for Canavan's disease to Tay Sachs screening, and genetic screening in general. We have published our position statements about the lack of apparent benefit from treating children with Down syndrome with Piracetam and nutrition supplements. The Dysmorphology Subcommittee
(Chris Cunniff, MD, Chair) has developed and published suggestions for the work-up of individuals with mental retardation. Currently, they are developing guidelines for the evaluation of the stillborn infant. The $\alpha$-fetoprotein (AFP) and Related Analytes Subcommittee (Ira Salafsky, MD, Chair) has developed commentaries on folic acid supplementation and is now addressing the issue of genetic screening in the first trimester.

\section{Laboratory Practice Committee}

\section{Michael S. Watson, PhD, Chair}

The Laboratory Practice Committee has initiated several new projects. After the NIH Cystic Fibrosis Consensus Conference, it was immediately recognized that testing for CF mutations is relatively straightforward, but that the delivery system of screening parents for carrier status in primary care settings is not fully developed. A mechanism for providing the full spectrum of services with CF carrier screening tests was needed. This activity is being included under a new committee chaired by Robert Desnick, MD, PhD. This committee is also facilitating the transfer of new tests and technologies into clinical investigation and practice, ensuing development of guidelines for analytic components of tests, billing and reimbursement issues, regulatory agency interaction, etc.

\section{Quality Assurance Subcommittee}

\section{Shivanand Patil, PhD and C. Sue Richards, PhD, Co-chairs}

The Quality Assurance Subcommittee of the Laboratory Practice Committee has been responsible for the development and maintenance of the "Standards and Guidelines for Clinical Genetics Laboratories." First published in 1994 , the manual is going into its second edition. This edition will address the limited number of concerns expressed by members and will add a new section on the interphase and metaphase fluorescence in situ hybridiza tion (FISH) testing and several methods in molecular genetic testing. The College's Standards and Guidelines have been used by laboratories as part of their quality assurance programs and by regulatory bodies in the develf opment of their requirements for genetic laboratories.

\section{Committee on Economics of Genetic Services (COEGS)}

David Flannery, $M D$, and Wayne Miller, MD, Co-chairs

The most significant news from the COEGS regards the final approval of our revised proposal for CPT codes for Cytogenetics, Molecular Genetics, and Biochemical Genetics tests. Effective January 1, 1999, these new codes will incorporate improved cytogenetics codes, FISH codes, an expansion of codes in molecular diagnostics which includes components of protein trun cation tests, and DNA sequencing. After a long period oit education and discussion with the CPT Editorial Panel including Michael Watson, Wayne Grody, and Piero Rinaldo, the revamped system was approved and 